Fakultas Hukum Universitas Lancang Kuning, Jalan Yos Sudarso KM 8 Rumbai Pekanbaru, Riau,

Kode Pos 28266. Telp: (+62761)-51877

E-mail: jurnal.respublica@ac.id

Website: https://journal.unilak.ac.id/index.php/Respublica

\title{
Perlindungan Penata Laksana Rumah Tangga (PLRT) Indonesia
}

\author{
Hengki Firmanda ${ }^{\mathrm{a}}$, Andre Antonius ${ }^{\mathrm{b}}$ \\ a Fakultas Hukum, Universitas Riau, Pekanbaru, Indonesia, Email: hengki.firmanda@lecturer.unri.ac.id \\ b S2 Ilmu Hukum, Fakultas Hukum, Universitas Riau, Pekanbaru, Indonesia.
}

\begin{tabular}{l} 
Article Info \\
\hline Article History: \\
Received : 20-04-2020 \\
Revised : 13-05-2020 \\
Accepted : 19-05-2020 \\
Published : 28-05-2020
\end{tabular}

Keywords:

Protection

Migrant Worker

Domestic Worker

\section{Informasi Artikel}

Histori Artikel:

Diterima : 20-04-2020

Direvisi : : 13-05-2020

Disetujui : :19-05-2020

Diterbitkan : 28-05-2020

\section{Kata Kunci}

Perlindungan

Buruh Migran

Buruh Domestik

\begin{abstract}
Protection of migrant workers, especially those working in the informal areas, has become a serious problem in several countries, including Indonesia. Informal migrant workers such as domestic helpers, including one of the areas that get the most attention because of the lack of protection afforded to them. The rights of migrant workers are often violated only for the sake of economic benefits to both sending and receiving countries. This condition makes the government of each country should seriously think about the social protection of migrant workers. linformal migrant workers were limited into consideration in discussions related to the social protection of labor, even though they work in the working area that very vulnerable to exploitation. This paper will examine qualitatively the comparative law approach to the problem of informal social protection of migrant workers between Indonesia and Malaysia. The results showed that the legal status of migrant workers are often not regulated informally legislation in the host country (Malaysia) that their protection does not exist in law or in practice, in addition to the problems of bureaucracy and politics also became an obstacle for domestic workers in getting access to social protection.
\end{abstract}

\section{Abstrak}

Perlindungan buruh migran, terutama yang bekerja di sektor informal, telah menjadi masalah serius di beberapa negara, termasuk Indonesia. Buruh migran informal seperti pembantu rumah tangga (PRT), termasuk salah satu bidang yang paling mendapat perhatian karena kurangnya perlindungan yang diberikan kepada mereka. Hak-hak buruh migran seringkali dilanggar hanya demi keuntungan ekonomi bagi negara pengirim dan penerima. Kondisi ini membuat pemerintah masing-masing negara harus serius memikirkan perlindungan sosial buruh migran. buruh migran linier terbatas menjadi bahan pertimbangan dalam diskusi terkait perlindungan sosial tenaga kerja, meskipun mereka bekerja di wilayah kerja yang sangat rentan terhadap eksploitasi. Makalah ini akan mengkaji secara kualitatif pendekatan hukum komparatif terhadap masalah perlindungan sosial buruh migran informal antara Indonesia dan Malaysia. Hasil penelitian menunjukkan bahwa status hukum buruh migran yang kerap tidak diatur undang-undang informal di negara tuan rumah (Malaysia) bahwa perlindungan mereka tidak ada dalam hukum atau dalam praktik, selain masalah birokrasi dan politik juga menjadi kendala bagi rumah tangga. pekerja dalam mendapatkan akses ke perlindungan sosial. 


\section{PENDAHULUAN}

Data International Organisation for Migration (IOM), diperkirakan sekitar 3\% dari seluruh penduduk dunia atau sebesar 214 (dua ratus empat belas) juta adalah buruh migran. ${ }^{1}$ Diprediksi pada tahun 2050 akan meningkat tajam menjadi 400 juta orang. Pada tahun 2010, IOM memperkirakan jumlah buruh migran dari Asia Tenggara mencapai 10,2 juta orang, dengan rincian sekitar 6,7 juta orang bekerja di negara-negara Asia Tenggara, 3,2 juta bekerja di Amerika Serikat, dan sisanya bekerja di wilayah Iain, terutama di negara-negara teluk. ${ }^{2}$ Indonesia dan Filipina merupakan negara utama pengirim tenaga kerja, sedangkan Malaysia dan Thailand adalah negara penerima tenaga kerja terbanyak. Buruh migran terbanyak berada di negara Malaysia, Singapore dan Thailand yang berasal dari Kamboja, Indonesia, Myanmar, dan Filipina. ${ }^{3}$ Pada Januari tahun 2007, ASEAN mengadopsi the Declaration on the Protection and Promotion of the Rights of Migrant Workers.

Perlindungan terhadap HAM buruh migran sudah menjadi perbincangan hangat pada tingkat global, regional maupun nasional. Fokus utama adalah pencegahan terhadap kekerasan di tempat kerja maupun dalam kehidupan sehari-hari, sering kali dalam bentuk penyalahgunaan kekuasaan atau diskriminasi, khususnya dalam bidang kerja domestik atau Penata Laksana Rumah Tangga (PLRT). Namun demikian, upaya terhadap peningkatan perlindungan buruh melalui perlindungan sosial dan perluasan akses terhadap perlindungan sosial sering diabaikan, baik di negara pengirim (asal) maupun negara penerima. Sedikit sekali kebijakan dikeluarkan terkait hak-hak dasar buruh migran terhadap pensiun, cuti bersalin, maupun jaminan kesehatan. Kalaupun ada, pelaksanaan di lapangan masih belum maksimal. Masih banyak buruh migran yang tidak mendapatkan kompensasi pada kecelakaan kerja, baik terhadap buruh berdokumen (legal) maupun buruh tidak berdokumen (illegal).

Peningkatan kasus penganiayaan terhadap PLRT Indonesia yang bekerja di Malaysia menambah keprihatinan kita terhadap tanggung jawab negara dalam melindungi warga negaranya. Peran negara menjadi semakin tidak nampak bila kita cermati kasuskasus yang teqadi terhadap PLRT Indonesia. Padahal kenyataannya sudah banyak yang langkah yang dilakukan oleh Pemerintah dalam menindaklanjuti dan melindungi PLRT Indonesia yang bekerja di luar negeri. Bahkan Memorandum of Understanding (MoU) yang telah dibuat dengan pemerintah Malaysia juga sudah cukup banyak. Terakhir setelah masa moratorium, Indonesia dan Malaysia kembali membuat Perjanjian Bilateral dalam Bentuk MoU Protokol Amandemen MoU Perekrutan dan Penempatan Penata Laksana Rumah Tangga Indonesia di Malaysia tahun 2011.

\footnotetext{
${ }^{1}$ IOM, World Migration Report 2010 (Geneva: IOM, 2010).

2 Ibid

${ }^{3}$ Tamagno, E., Strengthening Social Protection for ASEAN Migrant Workers Through Social Security Agreements (Bangkok: ILO, 2008).
} 
Artikel ini akan mencoba membahas lebih lanjut terkait permasalahan perlindungan PLRT, termasuk hak untuk mendapatkan pensiun, hak terhadap jaminan kesehatan, pemberian cuti bersalin, rehabilitasi dan kompensasi kecelakaan kerja khususnya bagi PLRT Indonesia di Malaysia. Tujuannya adalah mendapatkan sebuah konsep perlindungan PLRT Indonesia yang memenuhi prinsip-prinsip fundamental Hak Asasi Manusia.

Penelitian ini adalah penelitian yuridis normatif dengan pendekatan normatif. Pendekatan ini bertujuan untuk mendapatkan landasan hukum terkait permasalahan hukum nasional dan perlindungan sosial bagi buruh migran di negaranya masing-masing. Bahan-bahan hukum didapatkan dari berbagai sumber referensi dalam bentuk dokumen hukum, buku-buku, jurnal, makalah, maupun sumber sekunder lainnya.

\section{PERLINDUNGAN PENATA LAKSANA RUMAH TANGGA (PLRT) INDONESIA}

Indonesia dikenal sebagai salah satu negara pengirim tenaga kerja terbesar di dunia. Negara tujuan para Tenaga Kerja Indonesia (TKI)/Tenaga Kerja Wanita (TKW) tersebut di antaranya adalah Timur Tengah, Singapore, Malaysia, Taiwan, Korea, dan Hongkong. Ada kecenderungan terjadi peningkatan jumlah tenaga kerja yang bekerja ke luar negeri dari tahun ke tahun. Pada tahun 1980, jumlah tenaga kerja hanya berkisar 10.000 orang, sedangkan pada tahun 1998/1999, jumlah tersebut telah berkembang pesat menjadi lebih dari 600.000 orang. ${ }^{4}$

Feminisasi tenaga kerja dari laki-laki kepada tenaga kerja perempuan ini terutama menggejala pada pengiriman TKI ke Saudi Arabia, Uni Emirat Arab, Singapore, Hong Kong, dan Brunei. Kebanyakan pekerja perempuan tersebut dipekerjakan sebagai pembantu rumah tangga. Ada sejumlah besar pekerja perempuan Indonesia di Malaysia, Singapore, dan Hongkong yang dipekerjakan sebagai pekerja seks atau di tempat-tempat hiburan malam, tetapi tidak ada angka yang pasti tentang mereka. Proses feminisasi TKI ini antara lain dipicu oleh tingginya permintaan terhadap TKW dari negara-negara yang membutuhkan mereka sebagai pembantu rumah tangga dan oleh melimpahnya supply tenaga kerja untuk pekerjaan- pekerjaan yang tidak memerlukan keahlian (baik laki-laki maupun perempuan). ${ }^{5}$

Oleh karena itu, menjadi niscaya kepada para TKI/TKW tersebut diberikan perlindungan, baik itu dalam konteks perlindungan sosial atau pengaman sosial, maupun perlindungan hukum. Dimana sampai saat ini dirasakan masih banyak para TKI/TKW, yang menjadi korban baik fisik, psikis bahkan korban nyawa atas perlakuan para majikan ditempat mereka bekerja. Ironisnya, perlakuan tersebut berulang terjadi,

\footnotetext{
${ }^{4}$ Muhadjir Darwin, Pekerja Migran dan Seksualitas, Makalah dikutip dari full paper, Trafficking and Sexuality in Indonesia-Malaysia Cross-Border Migration, (2003).

${ }^{5}$ Ibid.
} 
namun perlindungan terhadap mereka baik dari Negara tempat mereka bekerja maupun dari perusahaan dan pemerintah Indonesia, masih sangat kurang. Padahal, begitu banyak penambahan devisa negara dari hasil mereka bekerja, sehingga mereka juga dikenal sebagai "Pahlawan Devisa”.

Istilah perlindungan sosial sering disamakan dengan jaminan sosial. Sulit untuk membedakan kedua pengertian tersebut secara umum. Terkadang juga memiliki pengertian yang berbeda tergantung dari negara atau instrumen yang digunakan. Menurut ILO, pengertian perlindungan sosial dan jaminan sosial dibedakan sebagai berikut: ${ }^{6}$ Social protection... is often interpreted as having a broader character than socia/ secur/y (including protection provided between members of the family or members of a local community) but ls also used In some context with a narrower meaning (understood as comprising only measures addressed to the poorest, most vulnerable or excluded members of society\}... social protection has the following aspects: (1) Interchangeable with social security; (2) as protection provided by socia/ security in case of social risks and needs. Social security covers all measures providing benefits, whether in cash or in kind, to secure protection from: (a) lack of work-related income (or sufficient income) caused by sickness, disability, maternity, employment injury, unemployment, old age or death of a family member; (b) lack of access or unaffordable access to health care; (c) insuffiecient family support, particularly for chlldren and adult dependents; and (d) general poverty and socia/ exclUslon... social security has /wo main dimensions, namely income securlty and avallability of medlcal care.

Perlindungan menurut Kamus Besar Bahasa Indonesia adalah tempat berlindung; perbuatan memperlindungi yaitu menjadikan atau menyebabkan berlindung. ${ }^{7}$ Perlindungan-perlindungan yang diberikan terhadap buruh migrant dapat diklasifikasikan sebagai berikut: ${ }^{8}$

a) Hak atas persamaan, merupakan hak yang diperoleh oleh buruh migran atas persamaan perlakuan dengan warga negara setempat oleh pemerintah setempat, dimana buruh migran berada dan perlakuan yang sama taanpa perbedaan antara jenis kelamin, ras, warna kulit, bahasa agama, atau kepercayaan, pendapat politik atau lainnya, kebangsaan, asal usul etnis atau sosial, kewarganegaraan, usia, kedudukan ekonomi, kekayaan, status perkawinan, status kelahiran, atau status lainnya.

b) Hak atas kebebasan pribadi, termasuk di dalamnya, yaitu hak kebebasan untuk bergerak, berpergian dan berpindah-pindah tempat, hak kebebasan mengeluaarkan

\footnotetext{
${ }^{6}$ ILO, World Social Security Report, (ILO: 2011), 13.

${ }^{7}$ Kamus Besar Bahasa Indonesia, (Jakarta: Gramedia Pustaka Utama, 2008), 830.

${ }^{8}$ Wiwiek Dwi Marchyani, Harmonisasi Aturan Hukum Buruh Migran antara International E:onventiaon on the Protection of the Rights of All Migrant Workers and Member of Their Families dan Undang-Undang Nasional, (Surakarta: Fakultas Hukum Universitas Sebelas Maret Surakarta, 2010), 53-93.
} 
pendapat, memilih dan aktif organisasi, dan menjalankan agama.

c) Hak atas rasa aman, merupakan suatu kondisi, setiap orang berhak atas perlindungan diri pribadi, keluarga, kehormatan, martabat, hak milik, rasa aman dan ketentraman, serta perlindungan terhadap ancaman ketakutan untuk berbuat atau tidak berbuat.

d) Hak atas kesejahteraan, yaitu setiap orang berhak mempunyai milik, baik sendiri maupun bersama orang Iain untuk pengembangan diri, bangsa dan masyarakat.

e) Hak memperoleh keadilan, yaitu setiap orang berhak keadilan dengan mengajukan permohonan, pengaduan, dan gugatan baik dalam perkara pidana, perdata, maupun administrasi Negara, serta diadili melalui proses peradilan yang bebas dan tidak memihak.

f) Hak mengembangkan diri, yaitu hak pengembangan diri pribadi maupun secara kolektif untuk membangun masyarakat, bangsa dan negaranya.

g) Hak turut serta dalam pemerintahan, yaitu hak yang digunakan baik secara langsung maupun melalui perwakilan dalam pemerintahan.

Sejak diberlakukannya Perjanjian Internasional mengenai Hak-hak Ekonomi, Sosial, dan Budaya, pada 3 Januari 1976 dan telah diratifikasi oleh 160 negara, termasuk Indonesia, bahwa dalam perjanjian ini berupaya meningkatkan 3 (tiga) kategori hak, yaitu:

a) Hak untuk bekerja dalam kondisi yang adil dan menguntungkan;

b) Hak atas perlindungan sosial, standar hidup yang pantas, standar kesejahteraan fisik dan mental tertinggi yang bisa dicapai;

c) Hak atas pendidikan dan hak untuk menikmati manfaat kebebasan kebudayaan dan kemajuan ilmu pengetahuan. ${ }^{9}$

Perangkat hukum dan politik pada tingkat internasional dan regional telah lama mengenal hak-hak terhadap perlindungan sosial atau jaminan sosial. Namun, beberapa waktu belakangan, kebijakan mulai lebih difokuskan pada hak-hak buruh migran. Beberapa kebijakan tersebut telah dituangkan dalam konvensi, rekomendasi, dan deklarasi terhadap pentingnya jaminan perlindungan sosial dan mekanisme pelaksanaannya yang bebas dari diskriminasi.

Aturan hukum (rule of law) tidak dipandang sebagai konsep pemersatu di antara Negara-negara ASEAN, tetapi konsep cair atau “protean”. Pada 2004 risalah yang berkembang tentang diskursus Asia mengenai rule of law, para sarjana mencirikan negaranegara ASEAN sebagai perlambangan "konsep rule of law yang bersaing” Selain negaranegara komunis Vietnam dan Laos, negara- negara ASEAN diklasifikasikan dua kategori, negara-negara otoriter, kurang-otoriter atau demokrasi terbatas (Myanmar, Malaysia, Singapura dan Brunei); dan negara- negara yang menampilkan konstitusionalisme dan

${ }^{9}$ Ibid, 32-33. 
keadilan transisi (Kamboja, Filipina, Thailand dan Indonesia). ${ }^{10}$

Kendati tingkat penerapan rule of law di masing-masing negara ASEAN bervariasi sesuai dengan konteks dan kapasitas khusus mereka, variasi-variasi ini tidak mencerminkan 'konsep-konsep yang bersaing' meskipun mereka adalah catatan-catatan yang berbeda pada daftar normatif yang sama untuk rule of law di ASEAN. Pada tahun 2004, dalam upaya untuk memajukan keseragaman di dalam penggunaan dan pemahaman tentang rule of law, Sekretaris Jenderal Perserikatan Bangsa-Bangsa ("PBB”) pada saat itu, Kofi Annan, menawarkan definisi berikut: mengacu pada prinsip tata pemerintahan dimana semua orang, institusi dan badan, publik dan swasta, termasuk Negara itu sendiri, bertanggung jawab kepada hukum yang diberlakukan secara umum, ditegakkan secara setara dan diputuskan secara independen, dan sejalan dengan norma-norma dan standarstandar hak asasi manusia internasional. Hal ini juga membutuhkan langkah-langkah untuk memastikan kepatuhan terhadap prinsip-prinsip supremasi hukum, persamaan di depan hukum, pertanggungjawaban hukum, keadilan di dalam penerapan hukum, pemisahan kekuasaan, partisipasi dalam pengambilan keputusan, kepastian hukum, penghindaran kesewenang-wenangan dan transparansi prosedural dan hukum. ${ }^{11}$

Salah satu instrumen standar internasional yang mengatur tentang perlindungan sosial adalah Pasal 3 Deklarasi Philadelphia (Tahun 1944) yang menjadi dasar dan tujuan umum dari pembentukan ILO. Pasal 22, 23, dan 25 Deklarasi Universal Hak Asasi Manusia (DUHAM) menegaskan perlindungan sosial sebagai hak universal seluruh umat manusia dalam kondisi apapun, termasuk jaminan terhadap minimum standar penghasilan yang layak. Pembahasan mengenai perlindungan sosial dalam DUHAM berkisar tentang minimum standar penghidupan yang layak seperti makanan, pakaian, rumah, layanan kesehatan dan hak untuk mendapatkan tunjangan apabila dalam keadaan pengangguran, sakit, disabilitas, kematian pasangan, lansia, ataupun usia balita. ${ }^{12}$

Perlindungan terhadap hak-hak buruh migran juga telah diatur dalam berbagai instrumen internasional. Pada tahun 1990, PBB telah melahirkan sebuah standar internasional tentang hak-hak buruh migran dalam the International Convention on the Protection of the Rights of All Migrants Workers and Members of Their Families (UN Migrant Workers Convention-UNMWC), yang mulai berlaku sejak tahun 2003. UNMWC telah diratifikasi oleh Indonesia melalui Undang-Undang Nomor 6 Tahun 2012. UNMWC bukan hanya memberikan perlindungan terhadap buruh migran, namun juga melindungi terhadap seluruh anggota keluarga mereka. Perlindungan yang diberikan dalan UNMWC dapat dirinci sebagai berikut:

\footnotetext{
${ }^{10}$ David Cohen, etc, (Ed), Rule of Law untuk Hak Asasi Manusia di Kawasan ASEAfl: Studi Awal, Human Rights Resources Centre, (Jakarta: Universitas Indonesia, 2011), 8.

${ }^{11}$ Ibid, 9.

${ }^{12}$ Pasal 9 dan 10 International Covenant on Economic, Social, and Cultural Rights.
} 
a) Hak buruh migran sesuai dengan CMW. Setiap buruh migran dan anggota keluarganya memiliki hak-hak yang meliputi untuk bekerja di luar negeri; Hak untuk memasuki dan tinggal di negara tujuan; Hak atas hidup yang harus dilindungi oleh hukum; Hak untuk tidak dapat dijadikan sasaran penyiksaan atau perlakuan atau penghukuman yang kejam, tidak manusiawi dan merendahkan martabat; Hak untuk tidak diperbudak; Hak untuk tidak diwajibkan melakukan kerja paksa atau kerja wajib; Hak kebebasan berfikir, berkeyakinan, beragama; Hak berpendapat; Hak kebebasan dan keamanan; Hak untuk diakui dimanapun sebagai pribadi di muka hukum; Hak untuk mendapatkan layanan kesehatan termasuk kesehatan reproduksi Hak untuk mentransfer dan menyimpan uang di bank; Hak untuk berlibur; Hak atas kebebasan untuk bergerak di wilayah negara tempat bekerja dan kebebasan untuk memilih tempat tinggalnya dalam wilayah tersebut; Hak untuk mendapatkan hak politik, berpartisipasi dalam masalah pemerintahan untuk memilih dan dipilih pada pemilihan umum, sesuai dengan ketentuan perundangundangan; Hal atas persamaan perlakuan sama dengan warga negara dari negara tempatnya bekerja; Hak atas tempat tinggal atau fasilitas umum dan sosial budaya; Hak untuk memilih pekerjaan; Hak atas peningkatan kapasitas diri baik melalui pendidikan formal maupun informal; Hak memiliki keterampilan, dan; Hak untuk menikah atau memiliki pasangan hidup sesuai dengan pilihan orientasi seksual.

b) Kewajiban buruh migran berdasarkan CMW, selain hak yang melekat pada buruh migran, juga terdapat kewajiban yang harus ditaati dan dilaksanakan oleh buruh migran antara Iain, Untuk menghormati hak atau nama baik orang Iain; Melindungi keamanan nasional atau ketertiban umum negara-negara yang bersangkutan atau ketertiban umum (order publik) atau kesehatan atau moral umum; Mencegah propaganda perang, dan; Mencegah upaya yang mendorong kebencian berdasarkan kebangsaan, ras atau keagamaan yang merupakan penghasutan untuk melakukan diskriminasi, permusuhan dan tindak kekerasan.

c) Hak dan Kewajiban Anggota Keluarga, Selain dari hak dan kewajiban yang dimiliki oleh buruh migran, anggota keluarga buruh migran juga memiliki hak yang melekat dengan kewajiban mereka, sama seperti dengan yang telah disebutkan di atas.

Pada tingkat regional ASEAN telah memiliki instrumen hukum tentang perlindungan social bagi buruh migran, diantaranya ASEAN Instrument on Protection and Promotion of the Rights of Migrant Workers (AIMW) yang dihasilkan dalam Viantiane Action Programme sejak tahun 2004 sampai dengan tahun 2010. Pada bulan Maret 2007, ILO dan ASEAN menandatangani perjanjian kerjasama yang memprioritaskan pengembangan dan pembangunan terhadap buruh migran. Pada Januari 2007, ASEAN menyetujui Declaration on the Protection and Promotion of the Rights of Migrant Workers (DPPMW). 
Pada bulan Juli 2007, Menteri Luar Negeri ASEAN mendirikan Komite the Implementation of the Declaration on the Protection and Promotion of the Rights of Migrant Workers (DPPMW), yang akan bertanggung jawab kepada Seniot Labour Officials Meeting (SLOM). Pertemuan pertama dilakukan pada tahun 2008 yang menghasilkan 4 (empat) prioritas kerja, yaitu:

a) meningkatkan perlindungan dan promosi terhadap hak-hak buruh migran terhadap eksploitasi dan perlakuan yang tidak layak;

b) memperkuat perlindungan dan promosi hak-hak buruh migran dengan menguatkan pengaturan terkait migrasi pekeqa di negara-negara ASEAN;

c) melakukan kerjasama regional dalam melawan human trafficking di wilayah ASEAN; dan

d) memperkuat institusi AIMW sendiri.

Pengesahan Piagam ASEAN pada KTT ke-13 pada bulan November 2007, ASEAN bergerak ke arah menjadi pemerintahan tunggal dan telah menyatakan komitmennya yang tegas untuk antara Iain meningkatkan rule of law dalam hal yang berkenaan dengan penggunaan dan definisi dari ekspresi ini oleh PBB. Piagam ASEAN telah memasukkan kepatuhan terhadap rule of law dan hubungannya dengan hak asasi manusia dan demokrasi sebagai tujuan dan prinsip utama ASEAN dimana semua negara anggota ASEAN telah berjanji untuk menegakkannya. Mukadimah dari Piagam ASEAN menyatakan bahwa negara-negara anggota ASEAN harus, antara Iain, mematuhi prinsip-prinsip demokrasi, rule of law dan tata pemerintahan yang baik, penghormatan dan perlindungan terhadap hak asasi manusia dan kebebasan-kebebasan dasar.

Definisi PBB yang diterima secara luas dan menggunakan Piagam ASEAN dan perkembangan-perkembangan terkait dapat diindentifikasi empat prinsip utama rule of law berikut dalam kaitannya dengan hak asasi manusia di ASEAN, yang keduanya formal dan substantif. Prinsip Utama I mempertanyakan apakah pemerintah, termasuk pejabat-pejabat dan agen-agennya tunduk pada Konstitusi dan peraturan perundangundangan lainnya. Prinsip Utama II mempertanyakan apakah undang-undang dan prosedur penangkapan, penahanan dan penghukuman tersedia secara terbuka, sah dan tidak sewenang-wenang. Prinsip utama ini terkait dengan penerapan negara atas hukum pidana untuk melindungi hak-hak dan kebebasan- kebebasan dasar seperti hak atas kemerdekaan, integritas fisik, keamanan pribadi, dan kepatutan prosedural di dalam hukum. Prinsip Utama III mempertanyakan apakah orang-orang mempunyai akses terhadap keadilan dimana proses pengesahan dan penegakan hukum dapat diakses, adil, efisien, dan berlaku sama. Prinsip Utama ini berkaitan dengan apakah hukum diundangkan secara terbuka dan diberlakukan sama, dan apakah orang-orang memiliki akses yang sama dan efektif terhadap proses peradilan. Prinsip Utama IV mempertanyakan apakah keadilan diputus oleh pengadilan dan lembaga-lembaga keadilan yang kompeten, tidak 
memihak dan independen. Sementara Prinsip Utama III terkait dengan akses terhadap keadilan, Prinsip Utama ini berkaitan dengan administrasi oleh pengadilan-pengadilan dan lembaga-lembaga peradilan lainnya dengan cara yang adil, independen dan tidak memihak.

Adapun kerangka pengaturan hukum (rule of law) di ASEAN dalam bentuk instrumen-insturmen perlindungan HAM yang berkaitan dengan perlindungan kemanusian dan buruh migran, antara Iain:

a) Konvensi Internasional tentang Penghapusan Segala Bentuk Diskriminasi Rasial (CERD);

b) Kovenan Internasional tentang Hak Ekonomi, Sosial dan Budaya (ICESCR);

c) Protokol Opsional pada Kovenan Internasional tentang Hak Ekonomi, Sosial dan Budaya (ICESCR);

d) Konvensi tentang Penghapusan Segala Bentuk Diskriminasi terhadap Perempuan (CEDAW);

e) Protokol Opsional pada Konvensi tentang Penghapusan Segala Bentuk Diskriminasi terhadap Perempuan (CEDAW);

f) Konvensi Menentang Penyiksaan dan Perlakuan atau Penghukuman Lain yang Kejam, Tidak Manusiawi atau Merendahkan Martabat Manusia (CAT);

g) Protokol Opsional pada Konvensi Menentang Penyiksaan dan Perlakuan atau Penghukuman Lain yang Kejam, Tidak Manusiawi atau Merendahkan Martabat Manusia;

h) Konvensi Internasional tentang Perlindungan Hak-Hak Semua Buruh Migran dan Keluarga Mereka (ICRMW); dan,

i) Protokol Melawan Penyelundupan Buruh Migran melalui Darat, Laut dan Udara.

Berdasarkan track record sebelumnya, maka pelaksanaan seluruh agenda kerja ini akan ditentukan oleh perwakilan dari negara-negara penerima buruh migran (Malaysia dan Thailand) serta negara-negara pengirim buruh (Indonesia dan Philippina). Rencana kerja telah didiskusikan sejak tahun 2009, dimana Indonesia dan Philippina mengajukan agar perlindungan diberikan juga kepada undocumented workers, yang kemudian ditolak oleh Malaysia.

Elemen penting dalam integrasi ekonomi ASEAN adalah sistem perlindungan sosial, khususnya bagi buruh migran, untuk menjamin agar mereka tetap mendapatkan jaminan sosial walaupun sedang bekerja di luar negaranya sendiri. Negara-negara ASEAN harus membuat perjanjian-perjanjian bilateral terkait perlindungan sosial terhadap buruh migran dan keluarganya, khususnya antara negara pengirim dan penerima buruh migran. Namun sampai saat ini, belum ada perjanjian bilateral yang dibuat oleh negara anggota yang khusus mencakup perlindungan sosial buruh migran ini. Bahkan MoU yang semula 
dibuat untuk melindungi buruh migran, dianggap belum mampu memberikan perlindungan hukum yang cukup bagi buruh migran.

Indonesia sebagai salah satu negara pengirim buruh migran terbesar di kawasan ASEAN telah menandatangi beberapa instrumen hukum terkait perlindungan sosial terhadap buruh migran. 8 konvensi ILO yang merupakan fundamental konvensi telah ditandatangani oleh Indonesia. Adapun konvensi yang telah ditandatangani tersebut mengatur 4 prinsip fundamental dan hak di tempat kerja bagi buruh migran, terdiri dari kebebasan untuk berserikat dan bernegosiasi secara kolektif; penghapusan segala bentuk kerja paksa atau kerja yang diwajibkan; penghapusan pekerja anak; dan penghapusan diskriminasi dalam pekerjaan dan jabatan. Hal ini menujukkan keseriusan Indonesia dalam menjaga hak-hak buruh migran.

Pada saat ini, Indonesia masih merujuk pada Undang-Undang Nomor 39 Tahun 2004 tentang Penempatan dan Perlindungan Tenaga Kerja Indonesia di Luar Negeri (UUPPTKILN). UUPPTKILN memiliki asas-asas dan tujuan yang hendak dicapai dalam penempatan dan perlindungan calon TKI/TKI. Adapun asas-asasnya adalah "berasaskan keterpaduan, persamaan hak, demokrasi, keadilan sosial, kesetaraan, dan keadilan gender, anti diskriminasi, serta anti perdagangan manusia”. ${ }^{13}$ Sedangkan yang menjadi tujuannya adalah:

a) Memberdayagunakan dan mendayagunakan tenaga keqa secara optimal dan manusiawi:

b) Menjamin dan melindungi calon TKI/TKI sejak di dalam negeri, di negara tujuan, sampai kembali ke tempat asal di Indonesia;

c) Meningkatkan kesejahteraan TKI dan keluarga. ${ }^{14}$

Asas-asas dan tujuan dari dibentuknya UU PPTKILN tersebut diatas, ternyata secara umum substansi UU PPTKILN tidak sesuai dengan asas dan tujuannya. UU PPTKILN lebih banyak mengatur tentang tata niaga penempatan dari pada mengatur tentang perlindungannya. Terlihat jumlah Pasal yang mengatur perlindungan hanya 8 Pasal dari 109 Pasal atau sekitar 7\% jumlahnya. Sebaliknya pengaturan penempatan ada 66 Pasal atau sekitar 38\%. Perbedaan persentase jumlah Pasal demi Pasal dalam UU PPTKILN tidak serta merta dapat dijadikan tolak ukur untuk menilai lemah atau tidak lemahnya suatu aturan hukum. Sehingga perlu lebih lanjut analisis Pasal demi Pasal dalam UU PPTKILN.

Beberapa pakar ahli hukum ketenagakeqaan menjelaskan tentang kelemahan UU PPTKILN, diantaranya Agusmidah menjelaskan ada 5 analisa normatif terhadap

\footnotetext{
13 Pasal 2 UU PPTKILN.

${ }^{14}$ Pasal 3 UU PPTKILN.
} 
kelemahan substansi UU PPTKILN yakni Analisa terhadap kelemahan UU PPTKILN ${ }^{15}$ dapat dianalisis dari beberapa pasal yang terkandung di dalamnya. Pada Pasal 4 yang berbunyi: “Orang perorangan dilarang Menempatkan warga negara Indonesia untuk bekerja di luar negeri.” Ketentuan ini inskonsistensi (bertentangan) dengan Pasal 30 yang menetapkan bahwa setiap orang dilarang menempatkan calon TKI/TKI pada jabatan dan tempat pekerjaan yang bertentangan dengan nilai-nilai kemanusiaan dan norma kesusilaan serta peraturan perundang-undangan, baik di Indonesia maupun di negara tujuan atau di negara tujuan yang telah dinyatakan tertutup sebagaimana dimaksud dalam Pasal 27. Kata 'setiap orang' dalam merujuk pada orang perseorangan yang dalam Pasal 4 dilarang melakukan penempatan, sehingga kedua pasal ini akan menimbulkan ketidakpastian hukum. Sebaiknya subjek dalam Pasal 30 lebih diperjelas sehingga ketentuan ini dapat efektif.

Pada Pasal 20 ayat (1) yang berbunyi, "Untuk mewakili kepentingannya pelaksana penempatan TKI swasta wajib mempunyai perwakilan di Negara TKI ditempatkan”. Kewajiban ini tidak disertai sanksi pidana, padahal substansinya untuk membangun sistem penempatan TKI di Luar Negeri yang memperhatikan perlindungan kerja. Sanksi administratif saja belum cukup kuat. Sanksi hukum yang tidak tegas belum menjadikan ketentuan ini norma hukum, melainkan sekedar norma sosial atau norma sopan santun.

Pada Pasal 21 ayat (1), yang berbunyi, ”PPTKI swasta dapat membentuk Kantor cabang di daerah di luar wilayah domisili kantor pusatnya”. Dari segi substansinya Pasal di atas sangatlah penting dan strategis dalam proses rekruitmen yang tepat untuk mencegah hal- hal yang tidak sesuai seperti TKI illegal, human traffiking, penipuan dan pencaloan, dan sebagainya, namun rumusan "dapat” yang dapat diartikan "boleh" menjadi tidak sesuai dengan maksud yang dituju, sebaiknya Pasal ini merumuskan ”harus”, sehingga tujuan rumusan pasal tersebut tercapai.

Pasal 24 ayat (2) menyatakan bahwa "Mitra usaha sebagaimana dimaksud ayat (1) harus berbentuk badan hukum yang didirikan sesuai dengan peraturan perundangan di negara tujuan”. Pasal ini tidak akan efektif karena subjek hukum berada di luar batas wilayah Indonesia.

Pasal 29 ayat (1): "Penempatan calon TKI/TKI di luar negeri diarahkan pada jabatan yang Tepat sesuai dengan keahlian, keterampilan, bakat, minat dan kemampuan”.

\footnotetext{
15 Aloysius Uwiyono, Aspek Yuridis Penempatan dan Perlindungan Tenaga Kerja Indonesia Di Luar Negeri, Makalah, Seminar tentang Penempatan dan Perlindungan Tenaga Kerja Indonesia Di Luar Negeri, Penyelenggra BPHN, FH Unair dan Kanwil Depkum dan Ham Prov.Jawa Timur, Surabaya, 30-31 Agustus 2005. Dirangkum dan diolah kembali dalam Agusmidah, Tekad Memberantas Perdagangan Perempuan dan Anak Dengan Memberi Advokasi Penegakkan Hukum Melalui UU No.21 Tahun 2007, Makalah, Dialog Interaktif, Diselenggarakan oleh IKA FH USU Medan, 30 Agustus 2007 di FH USU Medan, 13.
} 
Ketentuan ini juga tidak memberi kejelasan siapa subjek hukumnya, sehingga si pelanggar dapat dikenakan sanksi. Rumusan di atas perlu dikonkritkan menjadi norma hukum dengan demikian sanksi hukum dan siapa yang terkena kewajiban hukum menjadi jelas.

UU PPTKILN dalam sistem penempatan dan perekrutan buruh migran belum berpihak pada perlindungan tenaga kerja. Hal ini tercermin dalam hal-hal sebagai berikut: ${ }^{16}$

a) Pencalonan masih akan berlangsung karena tidak ada kewajiban PPTKIS untuk membentuk kantor cabang di daerah rekrut;

b) Penempatan ilegal masih terbuka lebar karena tidak ada ketentuan tegas yang melarang;

c) Pelatihan yang diserahkan pada PPTKIS menimbulkan permasalahan pengawasan yang umumnya masih lemah;

d) Ditemukan ketentuan-ketentuan yang tidak jelas subjek hukumnya padahal dapat diancam sanksi pidana;

e) Ditemukan ketentuan yang lemah yang dirumuskan dalam bentuk kebolehan padahal sebaliknya keharusan;

f) Ada ketentuan yang dirumuskan sebagai keharusan namun tidak ada ancaman sanksi pidananya;

g) Adanya peraturan yang bertentangan (inkonsistensi);

h) Adanya ketentuan yang tidak efektif karena mengatur subjek hukum yang berada di luar batas NKRI.

Berdasarkan laporan Independen organisasi Non Pemerintah Indonesia menyebutkan "perlindungan dan penanganan kasus-kasus buruh migran perempuan Indonesia mulai dari pra pemberangkatan, masa kerja, dan pasca pemulangan, belum serius dilakukan oleh instansi pemerintah dan swasta yang terkait, karena faktanya buruh migran yang hampir $80 \%$ adalah perempuan, mengalami penyiksaan, perkosaan dan pelecehan seksual, deportasi, menjadi korban perdagangan perempuan, upah tidak dibayar, dan jam kerja yang panjang. ${ }^{17}$

Musni Umar menjelaskan kelemahan UU PPTKILN antara Iain: “dualisme pelayanan, TKI dijadikan komoditas pemerasan, perekrutan, seleksi calon TKI, kualitas TKI, perlindungan hukum dan jaminan asuransi”. ${ }^{18}$ Sedangkan Atik Krustiyati menjelaskan “dalam perkembangannya UU PPTKILN tidak dapat mengantisipasi

\footnotetext{
${ }^{16} \mathrm{Ibid}, 15-16$.

17 Organisasi Non Pemerintah Indonesia, Ringkasan Laporan Independen Organisasi Non Pemerintah Indonesia tentang Implementasi Konvensi Penghapusan Segala Bentuk Diskriminasi Terhadap Perempuan (Konvensi CEDAW di Indonesia), CEDAW Working Group Initiative, 2007, dalam http://jurnaIperempuan. com/2011/05/hak hak buruh pekerja perempuan/ \#respond, diakss pada 23 Mei 2020, pukul.22.10 WIB

18 Musni Umar, Penyumbang Devisa (Negara) Yang Terlantar, di unduh http://ahok.org/berita/ penyumbangdevi sa-negara-yang-terlantar/, diakses 23 Mei 2020, pukul 23.15 WIB
} 
persoalan TKI dan bahkan mengandung kelemahan-kelemahan, diantaranya pada Pasal 35 tentang usia calon TKI, Pasal 51 tentang kelengkapan dokumen, Pasal 102-104 tentang ketentuan pidana”. ${ }^{19}$

Kelemahan lainnya menurut Muhammad Fadhli menyebutkan: ${ }^{20}$

a) Cakupan perlindungan terbatas, dalam Pasal 1 angka 1 UU PPTKILN menyatakan dengan jelas bahwa yang dimaksud dengan "TKI adalah setiap warga negara Indonesia yang memenuhi syarat untuk bekerja di luar negeri dalam hubungan kerja layak untuk jangka waktu tertentu dengan menerima upah”. Kemudian angka 4 menjelaskan “..perlindungan hanya diberikan pada calon TKI/TKI dari tahap pra penempatan, penempatan dan puma penempatan”. Artinya Undang-Undang ini hanya mencakup perlindungan yang diberikan pada warga negara Indonesia yang memenuhi persyaratan untuk periode tertentu. Dengan demikian TKI ilegal tidak tercakup dalam UU PPTKILN dan berarti tidak akan menerima perlindungan;

b) Ketidak jelasan kewenangan hukum antara Kemenakertrans dan BNP2TKI, banyak Pasal-Pasal yang overlap (tumpang tindih) dan persoalan multi tafsir, misal Pasal 26 dan 95 UU PPTKILN. Sehingga tugas pokok dan Kemenakertrans dan BNP2TKI belum jelas. kemudian di bagian perlindungan sebagian besar kewajiban pemerintah justu dilimpahkan pada PPTKIS, yakni seperti melindungi TKI sesuai dengan perjanjian penempatanannya;

c) Hak-hak anggota keluarga TKI, dalam UU PPTKILN tidak diatur sama sekali hak anggota keluarga TKI untuk mendapatkan informasi. Padahal tujuan TKI bekerja salah satunya adalah untuk menghidupi keluargannya, hal ini mengindikasikan jika terjadi permasalahn terhadap TKI maka keluarga TKI tidak harus segera mendapatkan akses informasi.

d) Minimnya kewenangan pemerintah daerah, dalam Pasal 5 ayat (2) dikatakan “...pemerintah dapat melimpahkan sebagian wewenangnya dan/atau tugas pembantuan kepada pemerintah daerah sesuai peraturan perundang-undangan.” Kata 'dapat' dalam Pasal ini menunjukkan bahwa keterlibatan pemerintah daerah hanya terjadi pada saat tertentu jika dibutuhkan oleh pemerintah.

Adapun peraturan pelaksana lainnya dari UU PPTKILN antara Iain:

a) Instruksi Presiden No. 6 Tahun 2006 tentang Mereformasi Sistem Penempatan dan Perlindungan TKI;

\footnotetext{
${ }^{19}$ Atik Krustiyawati, TKI: Korban Ketidakadilan Atau Pahlawan Devisa, diunduh http://www.surabayapagi.com /index.php?3b1ca0a43b79bdfd9f9305b8129829621877b1a5d52fd52b66b15954c6a4bbc, di akses pada tanggal 23 Mei, pukul 23.17 WIB.

${ }^{20}$ Muhammad Fadhli, Implementasi Memorandum of Understanding tentang Perekrutan dan Penempatan Pekerja Domestik dalam Melindungi Penata Laksana Rumah Tangga Indonesia di Malaysia, (Lhokseumawe: FH Unimal, 2013).
} 
b) Peraturan Presiden No. 81 Tahun 2006 tentang Badan Nasional Penempatan dan Perlindungan TKI;

c) Keputusan Menteri Tenaga Kerja dan Transmigrasi No.KEP-14/MEN/1/2005 tentang Pencegahan TKI Non-Prosedur dan Jasa Pemulangan TKI;

d) Peraturan Menteri Tenaga Kerja dan Transmigrasi No.PER-04/MEN/III/2005 tentang Pelaksanaan Pembekalan Akhir Pemberangkatan TKI ke luar negeri;

e) Keputusan Menteri Tenaga Kerja dan Transmigrasi No.KEP-05/MEN/1/2005 tentang Peraturan Untuk Sanksi Administrasi dan Cara Menentukan Sanksi dalam Penempatan dan Perlindungan TKI di Luar Negeri;

f) Keputusan Menteri Tenaga Kerja dan Transmigrasi No.KEP-07/MEN/IV/2005 tentang Standar Akomodasi calon TKI;

g) Keputusan Menteri Tenaga Keqa dan Transmigrasi No. PER-19/MEN/V/2006 Tentang Pengelolaan Penempatan dan Perlindungan TKI di Luar Negeri;

h) Peraturan Menteri Tenaga Keqa dan Transmigrasi No. 1 Tahun 2012 Tentang Perubahan Atas Peraturan Menteri Tenaga Kerja dan Transmigrasi No. 7 Tahun 2010 Tentang Asuransi TKI;

Pada tataran hukum nasional, Indonesia telah merancang sebuah undang- undang baru terkait dengan perekrutan dan perlindungan pekerja Indonesia di luar negeri. Hakhak buruh migran, khususnya PLRT diakomodir sesuai dengan prinsip fundamental, yaitu:

a) Kebebasan untuk berserikat dan bernegosiasi secara kolektif, terdiri dari: Membentuk dan bergabung dalam serikat PLRT migran; Terlibat dalam negosiasi kolektif; Memilih perwakilan; Menggunakan sarana/media untuk arbitrase dan perdamaian; Mogok; Hak atas kebebasan dan keamanan pribadi; Bebas dari penangkapan dan penahanan semena-mena; Kebebasan untuk berpendapat dan berekspresi dan secara khusus bebas untuk mempertahankan pendapat tanpa campur tangan; Hak untuk mencari, menerima dan memberi informasi; Hak untuk diadili secara adil oleh pengadilan yang independen dan tidak memihak, dan; Hak atas perlindungan hak milik serikat pekerja.

b) Penghapusan segala bentuk kerja paksa atau kerja yang diwajibkan PLRT tidak boleh dipaksan bekerja di bawah ancaman hukuman; PLRT migran secara fisik tidak boleh dikurung; PLRT migran dapat mengakhiri atau diakhiri pekerjaannya sesuai dengan ketentuan hukum nasional; Pendisiplinan PLRT migran yang melanggar aturan tidak boleh dilakukan dalam bentuk kerja paksa, dan; PLRT yang terlibat dalam kegiatan mogok yang sah menurut undang- undang tidak boleh diminta bekerja secara paksa 
c) Penghapusan pekerja anak; Anak di bawah usia 15 tahun tidak diperbolehkan bekerja, bila terpaksa bekerja, jam bekerja tidak boleh lebih dari jam usai sekolah; Pekerjaan berbahaya tidak boleh dilakukan oleh anak-anak di bawah usia 18 tahun; Negara harus membuat sistem registrasi kelahiran untuk memonitor usia anak bekerja; Anak-anak PLRT berhak mendapatkan akte kelahiran, dan; Anakanak bebas dari bentuk-bentuk pekeqaan terburuk anak.

d) Penghapusan diskriminasi dalam pekerjaan dan jabatan. Larangan diskriminasi berdasarkan seks, ras, agama, etnis, status perkawinan, dan sebagainya. Secara khusus, sistem perlindungan sosial di Indonesia hanya terbatas pada asuransi tenaga kerja, yang hanya mencakup tenaga keqa formal saja. Pada tahun 2004, Indonesia sudah memberlakukan Undang-Undang Sistem Jaminan Sosial Nasional, yang memberikan akses pada jaminan kesehatan dan upah yang layak, khususnya terhadap lansia, pengangguran, orang sakit, kecelakaan kerja. Sampai saat ini, UU Jaminan Sosial Nasional ini sudah dirasakan dampaknya oleh sebagian kaum yang terpinggirkan, khususnya masyarakat miskin.

Malaysia memiliki sedikitnya 2.2 juta jiwa buruh yang berdokumen, atau hampir 20\% dari jumlah penduduk Malaysia sendiri, dan diperkirakan angka yang sama terhadap buruh yang tidak memiliki dokumen yang bekerja secara non prosedural di Malaysia. Sebagian besar buruh yang tidak memiliki dokumen ini merupakan korban dari trañcking, yang direkrut melalui penipuan atau dengan tujuan eksploitasi korban. Negara Malaysia tidak termasuk negara yang mengirimkan warga negaranya secara formal untuk bekerja di negara Iain. Warga negara Malaysia yang bekerja di negara Iain, bekerja sebagai tenaga kerja asing yang memiliki keahlian tertentu pada sektor formal, berbeda dengan tenaga kerja Indonesia yang mengirimkan tenaga kerja ke luar negeri, baik sektor formal maupun sektor informal. Hal ini membuat Malaysia belum merasa perlu untuk memiliki pengaturan khusus tentang penempatan tenaga kerja di luar negeri, termasuk badan atau instansi pemerintah khusus yang menangani tenaga kerja yang bekerja di luar negeri. 
Tabel 1

Perbandingan Ratifikasi Konvensi Indonesia dan Malaysia

\begin{tabular}{|c|c|c|c|}
\hline \multirow{2}{*}{ No } & \multirow{2}{*}{ Nama Konvensi } & \multicolumn{2}{|c|}{ Tanggal Ratifikasi } \\
\hline & & Indonesia & Malaysia \\
\hline 1 & $\begin{array}{l}\text { Kebebasan untuk berserikat dan bernegosiasi } \\
\text { secara kolektif: } \\
\text { a) Konvensi ILO No. } 87 \text { Tahun } 1948 \\
\text { tentang Kebebasan Berserikat dan } \\
\text { Hak untuk Berorganisasi; } \\
\text { b) Konvensi ILO No. } 98 \text { Tahun } 1949 \\
\text { tentang Hak untuk Berorganisasi dan } \\
\text { Bernegosiasi Secara Kolektif }\end{array}$ & $\begin{array}{l}\text { 09 Juni } 1998 \\
15 \text { Juli } 1957\end{array}$ & 05 Juni 1961 \\
\hline 2 & $\begin{array}{l}\text { Penghapusan segala bentuk kerja paksa atau } \\
\text { kerja yang diwajibkan: } \\
\text { a) Konvensi ILO No. } 29 \text { Tahun } 1930 \\
\text { tentang Kerja Paksa } \\
\text { b) Konvensi ILO No. } 105 \text { Tahun } 1957 \\
\text { tentang Penghapusan Kerja Paksa }\end{array}$ & $\begin{array}{l}12 \text { Juni } 1950 \\
07 \text { Juni } 1999\end{array}$ & $\begin{array}{l}11 \text { Nov } 1957 \\
13 \text { Okt } 1958\end{array}$ \\
\hline 3 & $\begin{array}{l}\text { Penghapusan pekerja anak } \\
\text { a) Konvensi ILO No. } 138 \text { Tahun } 1973 \\
\text { tentang Usia Minimum } \\
\text { b) Konvensi ILO No. } 182 \text { Tahun } 1999 \\
\text { tentang Bentuk- Bentuk Pekerjaan } \\
\text { Terburuk Anak }\end{array}$ & $\begin{array}{l}\text { 07 Juni } 1999 \\
28 \text { Maret } 2000\end{array}$ & $\begin{array}{l}09 \text { Sept } 1997 \\
10 \text { Nov } 2000\end{array}$ \\
\hline 4 & $\begin{array}{l}\text { Penghapusan diskriminasi dalam pekerjaan } \\
\text { dan jabatan } \\
\text { a) Konvensi ILO No. } 100 \text { Tahun } 1951 \\
\text { tentang Upah yang Sama } \\
\text { b) Konvensi ILO No. } 111 \text { Tahun } 1958 \\
\text { tentang Diskriminasi dalam Pekerjaan } \\
\text { dan Jabatan }\end{array}$ & $\begin{array}{l}11 \text { Agt } 1958 \\
07 \text { Juni } 1999\end{array}$ & 09 Sept 1997 \\
\hline
\end{tabular}

Tabel di atas menunjukkan keseriusan Indonesia dalam menjaga hak-hak buruh begitu besar dengan cara meratifikasi kedelapan konvensi pokok ILO tersebut. Namun berbeda halnya dengan Malaysia yang sampai saat ini masih belum mengakui hak fundamental seorang buruh, yang ditujukkan dengan hanya meratifikasi sebagian saja.

Catatan perjalanan hingga terbentuknya MoU 2006. Perjanjian bilateral tentang ketenagakerjaan yang pernah dibuat oleh pemerintah Indonesia dan pemerintah Malaysia yakni dimulai dari tahun 1984 hingga sekarang adalah berbentuk Agreement, Agreed Minutes dan MoU. Walaupun dengan nama yang berbeda-beda, namun tetap disebut perjanjian internasional yang mempunyai akibat hukum. Efektif atau tidaknya suatu 
perjanjian yang dibuat untuk melindungi para pihak, itu lebih melihat kepada isi dari perjanjian tersebut. Hal demikian juga penulis lakukan terhadap MoU 2006 dan Protokol Amandemen MoU 2011.

Sementara itu, bila menilik dan menganalisis lebih mendalam isi dari MoU 2006, maka dapat dilihat bahwa MoU 2006 tidak menjamin adanya perlindungan hukum dan HAM bagi PLRT Indonesia di Malaysia, yakni dengan pertimbangan bahwa MoU 2006 yaitu:

a) Kebebasan Berserikat dan Hak Berunding Bersama, MoU 2006 sama sekali tidak mengatur tentang kebebasan berserikat dan hak berunding bagi PLRT. Hal tersebut salah satunya dikarenakan Malaysia belum meratifikasi Konvensi ILO No.87 tentang Kebebasan Berserikat dan Hak Berorganisasi, sementara Indonesia bahkan telah meratifikasi Konvensi ILO tersebut dan Konvensi ILO No.98 tentang Berlakunya Dasar-Dasar Hak Untuk Berorganisasi dan Untuk Berunding Bersama. Dengan demikian terlihat jelas bahwa pemerintah Malaysia tidak pro terhadap kebebasan berserikat, hak menorganisasikan diri, berunding bagi PLRT, dan mengungkapkan secara bebas pendapat mereka untuk tujuan meningkatkan kondisi kerja mereka.

b) Diskriminasi Pekerjaan, Pada Article I dikatakan bahwa "Domestic workers means a citizen of the Republic of Indonesia who ss contracting or contracted to work in Malaysia for a specified period of time for specific individual as a domestic servant as defined in the Employment Act1955. the Labour Ordinance Sabah (Chapter 67) and the Labour Ordinance Sarawak (Chapter76)".*Artinya Pasal ini tidak mengakui PLRT sebagai pekerja (workers) melainkan sebagai pembantu (servant), serta disesuaikan dengan pengertian yang terdapat dalam the Employment Act 1955,the Labour Ordinance Sabah (Chapter 67) dan the Labour Ordinance Sarawak (Chapter 76). Pengertian PLRT dalam ketiga aturan Malaysia ini juga sama halnya, dimana dikatakan dalam PART I PRELIMINARY, Interpretation the Employment Act 1955, serta the Labour Ordinance Sabah (Chapter 67) dan the Labour Ordlnance Sarawak (Chapter 76). "Director General” means the Director General of Labour appointed under subsection 3(1); “domestic servant” means a person employed in connection with he work of a private dwelling-house and not in connection with any trade, business, or profession calmed on by the employer in such dwelling-house and includes a cook, house-servant, butler, child's nurse, valet, footman, gardener, washerman or washerwoman, watchman, groom and driver or cleaner of any vehicle licensed for private use". ${ }^{21}$ Pengertian di atas

\footnotetext{
${ }^{21}$ Terjemahan: “Direktur Jenderal” adalah Direktur Jenderal Kerja ditunjuk berdasarkan ayat 3 (1); Pembantu rumah tangga” berarti orang yang diangkat sehubungan dengan pekerjaan sebuah hunian-rumah pribadi dan tidak dalam hubungan dengan suatu perdagangan, bisnis, atau profesi yang dijalankan oleh majikan sedemikian rumah tinggal dan termasuk masak, rumah-hamba, butler, perawat anak, pelayan, bujang, tukang kebun, tukang cuci atau tukang cuci, penjaga, pengantin pria dan sopir atau bersih dari setiap kendaraan lisensi untuk penggunaan pribadi.
} 
menggambarkan bahwa PLRT hanya membantu sebuah pekerjaan rumah tangga dalam satu keluarga. Namun mendefinisikan pembantu (servants) bukan sebagai pekerja (workers) ternyata membawa PLRT kehilangan atas hak-haknya yang sebagai pekerja. Bahkan istilah pembantu (servant) mempunyai konotasi bahwa seseorang yang bersikap tunduk mengakui adanya 'hutang' sebagai suatu kewajiban hukum. Karena hal demikian tersebut hampir tidak adanya warga Malaysia yang bekerja sebagai PLRT, melainkan pekerjaan PLRT di Malaysia itu didominasi oleh PLRT migran. Pemerintah Malaysia tidak berkeinginan melindungi PLRT, terlebih lagi PLRT migran. Hal tersebut dapat dilihat dalam Undang-undang ketenagakerjaan Malaysia atau yang disebut the Employment Act 1955 Sec 57 jelas-jelas menegaskan bahwa hak para PLRT yang diakui hanyalah yang terkait dengan pemutusan hubungan kerja dengan majikan. ${ }^{22}$ Sehingga PLRT tidak mendapatkan hak-hak Iain yang diberikan kepada semua pekerja yang bekerja di Malaysia. Adanya pembatasan-pembatasan seperti di atas, bertentangan dengan Pasal 2 Konvensi ILO No.111 tahun 1958 tentang Larangan Diskriminasi Dalam Bidang Pekerjaan dan Jabatan (diratifikasi melalui dengan Undang-Undang No.21 tahun 1999) sedangkan Malaysia belum meratifikasi, serta bertentangan dengan Pasal 25 ayat 1 Convention on the Protection of the Rights of All Mlgrant Workers and their FamillQS (CMW). ${ }^{23}$ Sementara itu juga bertentangan dengan Pasal 11 Convention on the Elimination of All Forms of DiSCrlmination against Women (CEDAW). Disisi Iain hak PLRT untuk melangsungkan pernikahan juga dibatasi, yang termuat dalam Apendix A point D Responsibilties of the Domestic Workers (iv) "7he government of malaysia reserves the right to revoke the work pass in the event that the domestic workers marry in malaysia during the period of employment'. ${ }^{24}$ Ketentuan ini sangat bertentangan dengan Pasal 11 ayat 2 dengan majikan.^0 Sehingga PLRT tidak mendapatkan hak-hak Iain yang diberikan kepada semua pekerja yang bekerja di Malaysia. Convention on the Ellmination

\footnotetext{
${ }^{22}$ Bunyi teks tersebut adalah sebagai berikut: PART XI DOMESTIC SERVANTS Sec 57 the Employment Act 1955 Termination of contract 'Subject to any express provision to the contrary contained therein, a contract to employ and to serve as a domestic servant may be terminated either by the person employing the domestic servant or by the domestic se/vans giving the other party fourteen days'notice of his intention to terminate the contract, or by the paying of an indemnity equivalent to the wages which the domesfic servant wOuld have earned in fourteen days: PrOvided that any such contract may be terminated by either party without notice and without the paying of an indemnity on the ground of conduct by the other party inconsistent with the terms and conditions of the contract.

${ }^{23}$ Convention on the Protection of the Rights of All Migrant Workers and their Families (CMW) disebutsebut sebagai pengakuan atas hak-hak seluruh buruh migran dan keluarganya. CMW disahkan tahun 1990 dan baru diratifikasi oleh 34 Negara. Sampai MoU 2006 ini dibuat, Indonesia dan Malaysia belum meratifikasinya, sehingga ada desakan dari komite buruh migran dan civil society agar Indonesia dan Malaysia segera meratifikasi CMW.

${ }^{24}$ Terjemahan: Pemerintah malaysia berhak untuk mencabut lulus kerja dalam hal PLRT menikah di malaysia selama masa kerja.
} 
of All Forms of Discrimination against Women (CEDAW). Pertentangan tersebut lagi-lagi menjadikan PLRT kehilangan atas haknya sebagaimana yang diakui dalam CEDAW. Padahal Indonesia dan Malaysia masing-masing telah meratifikasi CEDAW. Seharusnya pada perumusan naskah MoU 2006, ketentuan ini tidak diubah karena bertentangan dengan HAM.

c) Kerja Paksa atau Perbudakan, Kerja paksa atau perbudakan sejatinya tidak ada lagi di zaman modern seperti sekarang ini. Karena hal yang semacam itu populer pada zama penjajahan dulu. Namun, jika diteliti lebih lanjut kerja paksa atau perbudakan masih terjadi. Seperti yang telah dijelaskan sebelumnya terkait istilah PLRT bukan sebagai pekerja (domestic workers) melainkan disebut pembantu (servants), The Institute for Ecosoc Rights menyebutkan "Dalam praktiknya, konotasi ini tak berbeda dengan definisi 'budak', karena sekalipun dibatasi oleh kontrak waktu keqa (dua tahun), PLRT pada dasarnya adalah 'property' dari dan tunduk pada majikan yang bersangkutan. Dengan kata Iain Undang-undang ketenagakeqaan Malaysia ini memperbudak para PLRT secara umum dihadapan publik yang menyadarinya”. ${ }^{25}$ Dengan adanya ketentuan ini maka paspor yang semula dijaga sendiri oleh PLRT, berubah menjadi kewenangan majikan atau pihak agensi untuk menyimpannya, bahkan ketentuan ini dilegalkan dalam Undang-Undang Imigrasi Malaysia. Persoalan terjadi ketika salah satu pihak tidak cocok lagi dengan pihak lainnya, PLRT yang tidak mampu lagi bertahan dirumah majikan dan memilih melarikan diri otomatis akan dikenai cap sebagai pendatang haram karena tidak berdokumen (undocumentedj. Posisi sebagai PLRT migran tanpa dokumen bila tertangkap oleh otoritas Malaysia, maka akan dijatuhi hukuman selayaknya pendatang haram. ${ }^{26}$

d) Perlindungan Hukum PLRT, Ada 2 hal yang sangat mendasar sehingga perlindungan hak-hak PLRT bukan menjadi prioritas utama dalam pembentukkan MoU 2006 ini. Pertama, tidak terdapat 1 Pasal pun yang jelas mengatakan PLRT berhak atas perlindungan dan penegakan hukum (law enforcement) jika hak-haknya dilanggar oleh para pihak serta sanksi yang jelas juga tidak dicantumkan dalam MoU 2006. MoU 2006 hanya menyebutkan Articel 11 (2) "The respective Party shall take appropriate action against Employers or MRA or IRA or Domestic workers that contravene teh provisions of this MoU”, ${ }^{27}$ kedua, tidak ada mekanisme Control atas pelaksanaan dari MoU 2006 ini, yang ada hanya ketentuan tentang pembentukkan joint working group yang anggotanya terdiri dari pejabat terkait dari masing-

\footnotetext{
${ }^{25}$ Tim Peneliti The Institute for Ecosoc Rights, Atase Tenaga Kerja dan Perlindungan TKI antara IndonesiaMalaysia-Singapura, (Jakarta: Kerjasama dengan TIFA Foundation, 2010), 114-115.

${ }^{26}$ Tim Peneliti The Institute for Ecosoc Rights, Ibid, 18.

27 Terjemahan: Masing-masing Pihak harus mengambil tindakan yang tepat terhadap majikan atau MRA atau IRA atau PLRT yang bertentangan dengan ketentuan- ketentuan MoU ini.
} 
masing pemerintah dan jolnt working group betugas jika ada masalah yang timbul atas pelaksanaan MoU 2006.

e) Jaminan Sosial, Pada Apendix A Paragraph A Responsiblities of the Employer ix dikatakan "The employer shall provide coverag for domestic workers under the foreign workers compensation scheme as prescribed by the minister of human resources, Malaysia". ${ }^{28}$ Menurut Tenaganita terkait kelemahan Pasal ini Pengusaha bisa membeli polis asuransi dari 24 perusahaan asuransi yang disetujui. Kelemahan pasal ini semakin diperkuat pada Part I Interpreation and Aplication kompensasi pekerja Act 1952, pada makna 'pekerja’ pada ayat (2) huruf (c) dikatakan bahwa pembantu rumah tangga dikecualikan dari defenisi ini.

Oleh karena itu bagaimana bisa seorang PLRT dilindungi oleh undang-undang ini, sementara PLRT tidak diakui sebagai pekerja. Dalam praktek hukum internasional ketentuan itu bertentangan dengan Konvensi ILO No.121 Tahun 1964 tentang Santunan Cidera Kerja, Konvensi ILO No. 102 Tahun 1952 tentang (Standar Minimum) Jaminan Sosial.

\section{KESIMPULAN}

Perlindungan sosial terhadap buruh migran, khususnya yang bekerja di bidang informal, telah menjadi permasalahan yang ckup serius di beberapa negara, termasuk Indonesia. Buruh migran informal seperti penata laksana rumah tangga termasuk salah satu bidang yang paling banyak mendapatkan sorotan karena kurangnya perlindungan yang diberikan terhadap mereka. Hak-hak buruh migran sering dilanggar demi keuntungan ekonomis terhadap kedua negara pengirim maupun negara penerima. Kondisi ini membuat pemerintah masing-masing negara harus secara serius memikirkan perlindungan sosial terhadap buruh migran. Buruh migran informal sedikit sekali menjadi pertimbangan dalam diskusi-diskusi terkait perlindungan sosial tenaga kerja, padahal mereka bekerja di wilayah kerja yang sangat rentan eksploitasi. Status hukum buruh migran informalsering tidak diatur dalam peraturan perundang-undangan negara penerima (Malaysia) sehingga perlindungan terhadap mereka memang tidak ada secara hukum maupun secara praktis, selain itu masalah birokrasi dan politik juga menjadi kendala tersendiri bagi PLRT dalam mendapatkan akses terhadap perlindungan sosial.

\section{DAFTAR PUSTAKA}

IOM, World Migration Report 2010. Geneva: IOM, 2010.

Tamagno, E. Strengthening Social Protection for ASEAN Migrant Workers Through Social Security Agreements. Bangkok: ILO, 2008.

\footnotetext{
${ }^{28}$ Terjemahan: Majikan harus menyediakan cakupan untuk pekerja rumah tangga di bawah skema kompensasi pekerja asing seperti yang ditentukan oleh Menteri Sumber Daya Manusia, Malaysia.
} 
Darwin, Muhadjir. Pekerja Migran dan Seksualitas. Makalah dikutip dari full paper Trafficking and Sexuality in Indonesia-Malaysia Cross-Border Migration, 2003.

ILO. World Social Security Report. 2011.

Kamus Besar Bahasa Indonesia. Jakarta: Gramedia Pustaka Utama, 2008.

Marchyani, Wiwiek Dwi. Harmonisasi Aturan Hukum Buruh Migran antara International E:onventiaon on the Protection of the Rights of All Migrant Workers and Member of Their Families dan Undang-Undang Nasional. Surakarta: Fakultas Hukum Universitas Sebelas Maret Surakarta, 2010.

Cohen, David, etc, (Ed). Rule of Law untuk Hak Asasi Manusia di Kawasan ASEAfl: Studi Awal, Human Rights Resources Centre. Jakarta: Universitas Indonesia, 2011.

International Covenant on Economic, Social, and Cultural Rights.

International Convention on the Protection of the Rights of All Migrants Workers and Members of Their Families (UN Migrant Workers Convention-UNMWC).

Declaration on the Protection and Promotion of the Rights of Migrant Workers (DPPMW).

Undang-Undang Nomor 39 Tahun 2004 tentang Penempatan dan Perlindungan Tenaga Kerja Indonesia di Luar Negeri.

Uwiyono, Aloysius. Aspek Yuridis Penempatan dan Perlindungan Tenaga Kerja Indonesia

Di Luar Negeri. Makalah. Seminar tentang Penempatan dan Perlindungan Tenaga Kerja Indonesia Di Luar Negeri, Penyelenggra BPHN, FH Unair dan Kanwil Depkum dan Ham Prov. Jawa Timur, Surabaya, 30-31 Agustus 2005.

Agusmidah. Tekad Memberantas Perdagangan Perempuan dan Anak Dengan Memberi Advokasi Penegakkan Hukum Melalui UU No. 21 Tahun 2007. Makalah. Dialog Interaktif, Diselenggarakan oleh IKA FH USU Medan, 30 Agustus 2007 di FH USU Medan, 13.

Ringkasan Laporan Independen Organisasi Non Pemerintah Indonesia tentang Implementasi Konvensi Penghapusan Segala Bentuk Diskriminasi Terhadap Perempuan (Konvensi CEDAW di Indonesia), CEDAW Working Group Initiative, 2007.

Umar, Musni. Penyumbang Devisa (Negara) Yang Terlantar, diunduh http://ahok.org/berita/ penyumbangdevi sa-negara-yang-terlantar/, diakses 23 Mei 2020, pukul 23.15 WIB.

Krustiyawati, Atik. TKI: Korban Ketidakadilan atau Pahlawan Devisa, diunduh http:// www.surabayapagi.com/index.php?3b1ca0a43b79bdfd9f9305b8129829621877b1a5d52fd52b66b15954c6a4bbc, di akses pada tanggal 23 Mei, pukul 23.17 WIB.

Fadhli, Muhammad. Implementasi Memorandum of Understanding tentang Perekrutan dan Penempatan Pekerja Domestik dalam Melindungi Penata Laksana Rumah Tangga Indonesia di Malaysia, Lhokseumawe: FH Unimal, 2013.

Convention on the Protection of the Rights of All Migrant Workers and their Families (CMW).

Tim Peneliti The Institute for Ecosoc Rights, Atase Tenaga Kerja dan Perlindungan TKI antara Indonesia-Malaysia-Singapura, Jakarta: Kerjasama dengan TIFA Foundation, 2010. 